\title{
The Physical Beauty in Shakespeare's Sonnets
}

\author{
Chunli $\mathrm{Ma}^{1}$ \\ ${ }^{1}$ School of Foreign Languages, Zhongyuan University of Technology, Zhengzhou, China \\ Correspondence: Chunli Ma, School of Foreign Languages, Zhongyuan University of Technology, 41 \\ Zhongyuan Road, Zhengzhou, 450007, China. E-mail: karenma2005@163.com
}

Received: February 26, 2016 Accepted: March 18, 2016 Online Published: April 28, 2016

doi:10.5539/ells.v6n2p110 URL: http://dx.doi.org/10.5539/ells.v6n2p110

\begin{abstract}
Beauty, one of the most reoccurring words throughout Shakespeare's Sonnets, is the principal subject of the poet's meditation. "From fairest creatures we desire increase, / That thereby beauty's rose might never die" begins the first poem in the sonnet sequence, a statement about beauty that can be understood as the first articulation of the Sonnets' aesthetic agenda. Beauty in Shakespeare's Sonnets is represented in two dimensions: the physical beauty and the spiritual beauty. The physical beauty refers to the beauty of the body and the sensual pleasure derived from desires.By means of the illustration of the physical beauty, Shakespeare conveyed the aesthetical world which brings readers enjoyment and delight, moreover, the poet warns readers that the sensual pleasure should base on married chastity and social norms, otherwise, it would result in death and destruction. The account of sexual pleasure shows that on the one hand for enjoying the life itself, on the other hand, for leaving children behind to make the temporary time eternalized, thus returning back to timeless Garden of Eden. This returning course is the process of preserving beauty.This article only focuses on interpreting the physical beauty in the Sonnets, the part of the beauty in spiritual dimension will be presented in another one.
\end{abstract}

Keywords: the physical beauty, sensual pleasure, delight, the Sonnets, Shakespeare's aesthetics

\section{Introduction}

Beauty, one of the most reoccurring words throughout Shakespeare's Sonnets, is the principal subject of the poet's meditation (Note 1). Beauty in Shakespeare's Sonnets is influenced by Plato's Idea of Beauty which, as subject matter, is elucidated in Symposium and Phaedrus. As Vyvyan comments, nearly all Renaissance theorizing on love and beauty stem from the two great speeches of Socrates (Vyvyan, 1961, p. 15). However, the topic of beauty is expounded firstly by Socrates in Plato's Hippias Major. Beauty in Greek at that time generally refers to fineness, delicacy, perfectness, and the like. Socrates points out that what is beauty or beauty in the abstract, just like by wisdom wise people are wise, and by the good all good things are good, so that all things are beautiful, beautiful through beauty. In other words, by those things existing really, for it is not surely by their non-existing (287B-D) (Plato, 1854, pp. 222-223). That is to say, it is the very abstract beauty beautifies all other things. As a matter of fact, beauty in the abstract what Socrates discusses in Hippias Major is the Idea of Beauty was brought forward and fully developed in the later dialogues, Phaedrus and Symposium.

Beauty as a principal object in Shakespeare's Sonnets has been analyzed by critics and scholars. One of the remarkable studies is Dympna Callaghan's Shakespeare's Sonnets, in which "Beauty" has been discussed from two aspects-Breeding Beauty and Black Beauty, which is about the young man's ideal beauty that should be reproduced and the black woman's unconventional beauty. However, only several sonnets are included in this study (Callaghan, 2007, pp. 35-57). Stephen Medcalf in "Shakespeare on beauty, truth and transcendence" takes Sonnet 53 as an example to illustrate the young man's absolute or Platonic beauty in a detailed way, but Medcalf's focus is Shakespeare's Venus and Adonis (Medcalf, 1994, pp. 117-125). John Smith Harrison believes that Shakespeare is influenced much by Platonism, and Shakespeare identifies him with the absolute beauty of the Platonic philosophy in his sonnets. While Harrison only mentions Sonnet 105 and Sonnet 53 to prove his argument (Harrison, 1903, pp. 128-129). And other critical researches of Shakespeare's Sonnets relate to the subject of beauty, such as, Edward Hubler's The Sense of Shakespeare's Sonnets, T. W. Baldwin's On the Literary Genetics of Shakespeare's Poems \& Sonnets, Kenneth Muir's Shakespeare's Sonnets, David West's Shakespeare's Sonnets: with A New Commentary, Robert Matz'sThe World of Shakespeare's Sonnets: An Introduction. They either cover a few sonnets or only mention this subject without further illustration. It is a pity that few critical attentions have not been given the systematic study on the subject of beauty in Shakespeare's 
Sonnets.

Shakespeare's Beauty in the Sonnets is represented in two dimensions: the physical beauty and the spiritual beauty. The physical beauty refers to the beauty of the body and the sensual pleasures derived from desires. And the spiritual beauty means the beauty is ultra-utilitarian, here it denotes more the affectional enjoyment and spiritual delight which detach from the sensual desires. Both the young man's surpassing beauty and the lady's unconventional dark beauty are entered into particulars in the Sonnets. And it is evident that the theme of desire runs through the Sonnets, besides the highly eulogy of the beauty. In the Fair Young Man group (Sonnet, 1-127), the beauty of the young man, on the first level, is a possession that the young man embodies it. Moreover, its spiritual dimension is manifested, as the young man is the beauty's pattern from which everything beautiful are drawn and partaken of. Here, the young man is not a flesh body any more, but a transformed Plato's ultimate Form-Idea of Beauty. Harrison summarizes that, thus, Shakespeare, in the Sonnets, praises the beauty of the subject matter (the young man) by identifying him with the absolute beauty of the Platonic philosophy, and by describing him in accordance with this notion (Harrison, 1903, p. 128).

\section{The Beauty of the Body}

There is no doubt that the young man has an unsurpassed beauty. The first general impression of his appearance is the speaker's declaration in the first sonnet, "thou art now the world's fresh ornament, / And only herald to the gaudy spring" (11. 9-10), while, it is still not clear that how he looks like in a specific way. His abstract beauty does not unveil until Sonnet 18. And yet, as if it is not easy to tell such an indescribable beauty, only whereby the way of comparison, "shall I compare thee to a summer's day? / Thou art more lovely and more temperate" (11. 1-2), these remarkable first lines of Sonnet 18 make a first sketch of what the young man looks like. As we all know, summer is the most comfortable and favourable season in England, it is lovely, temperate, warm, as well as sunny, however, the young man is more lovely and more temperate than it, so that the beauty of the young man comes out gradually by the wonderful comparison. The poem uses conventional image of natural beauty to demonstrate that the beauty of the young man surpasses even the most sublime of these. And then, the young man as "beauty's pattern" is immediately claimed in next sonnet.

It is quite witty that the alluring beauty of the young man is stressed in Sonnets 27 and 28 which deal with the traditional theme of sleepless (Note 2). In Sonnet 27, the speaker reflects on how thoughts of the young man keep him awake, bringing him both comfort and sorrow, with the help of his imagination which "presents thy shadow to my sightless view, / Which like a jewel (hung in ghastly night) / Makes black Night beauteous, and her old face new" (11. 10-12). The image of the young man is conjured up to the speaker's eyes, like a jewel hung in ghastly night, making the old face of night new and beautiful. Sonnet 28, a thematic continuation of the previous poem, narrates that the speaker is at the point of emotional exhaustion and frustration due to his sleepless nights spent thinking about the young man, in his distress, the speaker attempts to placate both day and night by telling them that the young man has a such beauty that "thou art bright, / And dost him grace when clouds do blot the heaven; ... / When sparkling stars twire not thou gild'st the even" (11. 9-12), making the day beautiful and compensating for it being at times gloomy and overcast, like the brightest stars shining the night when the stars do not. Both sonnets are full of contrasts which are often expressed in the same line, for instance, weary and haste, repose and tired, mind and body, drooping and open, old and new, and so on, these opposite terms help to convey the speaker's twisted restlessness during day and night, the reason is his absolute devotion to the young man, meantime, the marvelous beauty of the young man is set off against the sky.

If the beauty of the young man is quite ambiguous until now, Sonnet 53 gives us a satisfying answer:

Describe Adonis, and the counterfeit

Is poorly imitated after you.

On Helen's cheek all art of beauty set,

And you in Grecian tires are painted new.

Speak of the spring and foison of the year,

The one doth shadow of your beauty show,

The other as your bounty doth appear,

And you in every blessed shape we know. (11. 5-12)

In it the fair youth is claimed as the archetype or defining image of all beauty, whether human or nature, male or female. By using the classical epitomes of beauty Adonis \& Helen, who are perfect examples of male and female respectively, the speaker asserts that, comparing with the young man, Adonis turns out to be a poor imitation of 
him, and the young man is represented anew in Grecian attire than Helen's natural beauty; as for spring and autumn, seasons of liveliness and plenty respectively, spring is just like the image of the young man's beauty, autumn of his generosity. Indeed, he can be recognized in every form blessed with beauty, in other words, every beautiful entity partakes of the young man's, as he is the perfect one. What's more, the central eight lines on representation have a nicely complicated structure of its own:

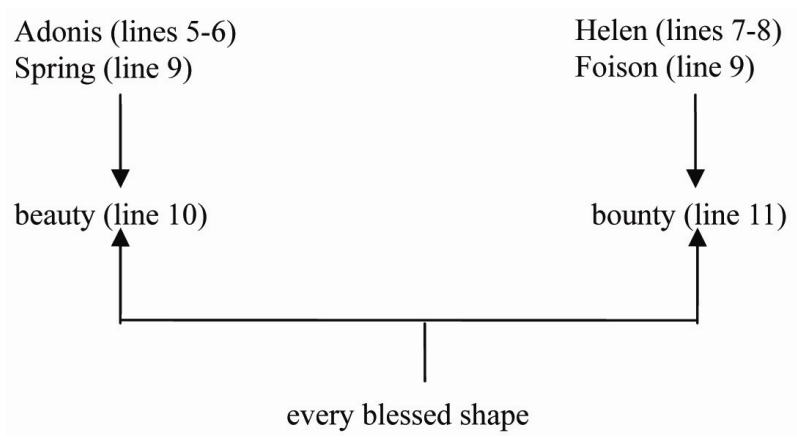

On the left, we have Adonis, on the right we have Helen; on the left we have spring, on the right, autumn. Left, beauty; right, bounty: everywhere we recognize the young man. This is a structure that confers an appropriate left-right gestural omnipresence, rather than an unfolding narrative temporality, on the philosophical question of multiple appearances (Vendler, 1998, p. 260).

Sonnets 67-70 form a fairly compact interrelated group, in which the young man's true beauty is discussed contrasting with the corruption and hypocrisy of the world that his beauty links to. Opening with questions why the young man should live among such infection, Sonnet 67 makes a defense that the presence of the young man's beauty can help to prop up those corruptions. He is so fair as to "poor beauty" seeks to imitate, and to steal "his living hue." Line 6, "And steal dead seeing of his living hue," describes the action of "false painting". It basically means that their attempts at copying his complexion only result in second rate imitations. And nature keeps him as an exemplar for present age and those to come to show what perfection was like in a past age. Contrary to the present artificial beauty, Sonnet 68 praises that the young man is a living example in the Golden Age. Line 9-In him these holy antique hours are seen - enacts a fresh start of praising the young man in the sestet, and making a conclusion that the young man's natural appearance is the model, "map" for all beauty for all ages. In Sonnets 67 and 68 the speaker had proclaimed the beauty of the young man, and the integrity which it symbolizes. Now, the first quatrain of Sonnet 69 still continues to praise such beauty, in it the speaker boldly utters that beauty of the young man is a truth which no one can deny, even to the extent that enemies have to admit that it is so, "All tongues (the voice of souls) give thee that due, / Utt'ring bare truth, even so as foes commend" (11. 3-4). But the tone seems to change in the rest of the poem, the world's eye does not blind the world, which knows that there are deeper truths than exterior beauty, as if the earlier praise of the young man's beauty is in a dilemma. They, the world, look into the beauty of the youth's mind.The apparent contrast with external beauty points to extreme irony, with the phrase "look into" taking the sense of close inspection, which indicates that such an inspection will reveal the opposite of a beautiful mind. However, on the other hand, as Hammond states, the speaker may well claim to intend "the beauty of thy mind" to be taken as literally true. The speaker believes in the young man and as he had done in Sonnets 67 and 68 in which he interprets his external beauty as an indicator of an even more beautiful interior (Hammond, 1981, pp. 116-121). The speaker's belief in the young man help him find out the excuse of the blame and slanderous mark for the young man in Sonnet 70, the answer is that such creatures like the young man, by their very nature, will attract slander. As the first stanza consoles "That thou art blamed shall not be thy defect, / For slander's mark was ever yet the fair. / The ornament of beauty is suspect, / A crow that flies in heaven's sweetest air," so that the young man is blamed is not in itself a defect, for beauty as a state which will always be subject to be attacked. "Shall not," in line 1, carries strong undertones of the speaker's power, as if it were an assertion that whatever others may say about the young man, he can apply a full defence (Vendler, 1998, p. 122). Actually, the next three lines provide with poetic idealism to oppose the world's slander, holding that "suspect" is the ornament of beauty, just like a crow winging its way in the pure air. "So thou be good," in the second quatrain, dissolves the doubt of there being a real defect in the young man, who is still good, the speaker goes on to repeat in substance the excuses for blame, which is due to not only slander, but also vice, is drawn towards beauty.

Creating an antithesis between the young man and the day, in Sonnet 18, the speaker muses, "you are the best 
thing I can think of, a summer day," "thou art more lovely and more temperate," such a surpassing beauty becomes the inspirer or Muse for the speaker, but now "every alien pen hath got my use, / And under thee their poesy disperse" (Sonnet 78, 11. 3-4). Specifically, the young man's eyes, having magical power, are identical with the "tenth Muse" in Sonnet 38. The young man's eyes "taught the dumb on high to sing," made ignorance fly, and add feathers, grace, and style even to the most learned poet. All these achievements on his part testify more impressively of the young man's beauty, "sweet grace." This inspiration, which the speaker invokes, raises him up "thou art all my art, and dost advance / As high as learning my rude ignorance" (11. 13-14). Even if this is an exaggeration for its own sake as a form of bonding flattery, it may speak as much to the young man as the speaker of himself and readers that how beautiful the young man is and how important he is.

The young man as beauty's pattern is uttered once more in Sonnet 98. The speaker's habit in more than one poem of measuring the young man's beauty against the splendors, especially the floral splendors, of nature, sticks in the mind. And he also succeeds in using images of song or the standard red and white hues of amorous delight to suggest the young man. Sonnet 98 makes the writing theme more specific. The first quatrain establishes the young man's absence, this time in the spring, even "heavy Saturn" is persuaded by April to laugh and leap, the gloomy speaker cannot; next quatrain begins the traditional what Leishman called "catalogue of uncompensating delights," the beauties of nature that cannot take the place of the beloved or compensate for the beloved's absence (Leishman, 1961, p. 186). In spite of the preceding refusals to be attentive enough to birds and flowers, the speaker makes a concession that, in the final line, he "did play" with all these flowers, until now, the riddle is resolved, as the flowers are representations (shadows) of the young man. The young man's beauty is the pattern for all the flowers drawn after, but they are imperfect copies of the young man's appearance, since "they were but sweet, but figures of delight" (1. 11). We, in Sonnet 98, are not told of that the speaker how to "play" with the flowers, Sonnet 99 gives us a minute report. However, Leishman condemns this poem as "a mechanical and tiresome piece of ingenuity, such as almost any Elizabethan sonneteer might have written, with a metaphorical list of flowers which have 'stolen' their beauties from his friend" (Leishman, 1961, p. 195). Indeed, comparing of one's beloved with the beauty of flowers is not a new theme (Note 3), but Sonnet 99 is not tiresome, if it is mechanical, it is mechanical with a purpose. This purpose is that telling us how these flowers steal the young man's beauty in a detailed way. The first quatrain, having five lines, chides the precocious violet directly for stealing a sweet odour from the "breath" of the young man, the "purple" colour from his "soft cheek;" next quatrain continues to blame the lily for assimilating the young man's hand and marjoram the fragrance of the hair; but the particoloured rose, the chief villian, has stolen the young man's one odour and red and white two colours. Probably, the charges are amplified in a sense, building from theft of colours to theft of colours and scent and concluding in line 12 with an additional accusation of pride, the speaker is only "playing" with these flowers, as he said in line 14 of Sonnet 98. As Vendler comments, there are no noncriminals in the world of Sonnet 99, and the couplet - "More flowers I noted, yet I none could see / But sweet or colour it had stol'n from thee"- -serves as a general exoneration: since all are guilty, none is (Vendler, 1998, p. 423). So the encompassed beauty and virtue of the young man are acted out in terms of the beauty and fragrance of these flowers. Shakespeare, like Petrarch or Ronsard, bewailing the absence of the beloved and drawing upon nature for appropriate imagery, but Shakespeare transforms both the theme and the imagery. He concentrates on using nature metaphorically to delineate the beauty and virtue of the young man rather than negative effects of the beloved one's absence.

The young man's inexpressible beauty is praised in Sonnet 106, which sounds like a paradox. The speaker, looking typologically into "the chronicle of wasted time" - as if all history led by prophecy to the young man whom he addresses, sees that poets, old and new, are unable to express fully the young man's supreme beauty. The octave enumerates a catalogue of excessive "praises" sung by the "antique pen" for the most beautiful people on earth. However, all these praises were mere prefigurings of the young man's glory, as for the young man's worth, they did not have such adequate power:

So all their praises are but prophesies

Of this our time, all you prefiguring,

And for they looked but with divining eyes,

They had not still enough your worth to sing. (11. 9-12)

It is important to notice that the words "praise" and "beauty" appear repeatedly in this sonnet, "praise" in lines 4, 9, and 14, "beauty" (lines 3, 3, 5, 8) and its synonyms "fairest" (1. 2), "lovely" (1. 4) and "best" (1. 5), according to Vendler's theory of reading the Sonnets, both "praise" and "beauty" are the key words. Evidently, the praises are excessive, which were heaped upon the "fairest wights," "Ladies dead," and "lovely knights," in other words, 
the young man as an epitome of all the "praises" by the "antique pen." But ironically, the speaker deplores the fact that although he wonders at excelling beauty of the young man he cannot praise it, he together with his contemporaries lacks the tongues to sing of it adequately. As the couplet admits that we may behold the young man's beauty and his worth, but we cannot enunciate them.

Traditionally, Sonnets 127-152 is regarded as the Dark Lady or Black Mistress group. The ideal of female beauty in Renaissance literature and sonnets is a blonde. The unconventional physical attraction of black mistress is eulogized in Dark Lady sequence. In the first sonnet of the group, Sonnet 127, the speaker speaks of the changing tastes dating from the 1590 s when blackness became the object of cultural fascination shared by most of his contemporaries. This taste had already had a biblical precedent in the Song of Solomon. However, blackness is not of the type normally admired, and the speaker must defend it while eulogizing, which gives a mildly unconventional twist to the opening poem, even though it barely hints at the unconventionalities to follow. In the first quatrain, the speaker points out that, in the past, "black," in the sense of the dark coloring of a brunette as opposed to the light coloring of a blonde, "was not counted fair" (1. 1), but now is "beauty's successive heir" (1. 3). Black's inheritance must be legitimate because illegitimate scions of the nobility were barred from inheriting titles, Callaghan notes that (Callaghan, 2007, p. 53). Even so, people still falsely say that this black child of beauty is a "bastard" (1. 4), since the heir of beauty is black. And then next quatrain tells us that in the days of cosmetic alteration one can no longer distinguish between true beauties and false beauties, which are made so by art. "Black" is truly beautiful and more likely to be genuine, in the sestet, the word "therefore" marks the transition, the speaker turns from generalizations to particularized application to the lady: "Therefore my mistress' eyes are raven black, / Her brow so suited, and they mourners seem" (11. 9-10), the noted feature of the mistress is her "raven black"eyes, together with her brow are "suited" for mourning, the "mourners" seem sad because of the prevalent "false esteem" of feminine beauty,

Yet so they mourn, becoming of their woe,

That every tongue says beauty should look so. (11. 13-14)

That is, the blackness of the mistress is symbolic of mourning for the debasement of true beauty. Black mourning now becomes so fashionable that "every tongue" has swung round to believing that dark beauties alone are truly beautiful.The mistress' eyes are black, like Sidney's Stella having black bright eyes, though the speaker does not imply, in this poem, the colour of her total appearance, we soon learn that the hair (Sonnet 130, 1. 4) and "complexion" (Sonnet 132, 11. 12-14) of the mistress are also "black."

Sonnet 130 brings about a new and better standard of beauty. Traditionally, the beloved woman always has fair hair like gold, bright eyes like sun or stars, pale complexion like ivory or snow, scarlet lips like coral, blushing cheeks like flowers, musical voice and sweet breath.Thus the speaker is well aware of the fact that his mistress is far from being beautiful in the conventional way, he manages to make fresh air upon traditional blazon. Unlike Sidney, whose "Stella's eyes" were Nature's "chief work" and "sun-like should more dazzle than delight," Shakespeare in the first line claims that, "My mistress' eyes are nothing like the sun," it is a bold contradiction of Petrarchan antecedent hyperbole. And then the speaker launches into a series of contrastive comparisons in the octave. In the sestet, as Vendler notes, love enters, beginning with perfume and breath, the speaker argues that just as speech cannot rival the aesthetic power of music, nor can anyone walk like a goddess (Vendler, 1998, p. 557), the speaker's mistress, unlike others', is a real woman, when she walks, she treads on the grounds. Throughout the whole poem, Shakespeare, moving from colours, red, white to black, and from red roses to white ones, and from roses to perfume and to breath, from goddess to heaven, places innovative pressure upon the limits of metaphoricity, which seems to undo nearly every Petrarchan conceit about feminine beauty employed by his fellow English sonneteers. Callaghan contends that "the point of this sonnet is not only that this particular woman does not meet the ideal standard of blonde Petrarchan beauty, but that no woman does" (Callaghan, 2007, p. 56), as the other women's beauty are actively misrepresented or "belie" by those sonneteers, the concluding couplet makes a defiant assertion that the dark lady is "as rare as any" since she has a different and new beauty pattern.

This different and new beauty is continued to be praised in Sonnet 132. The mistress' black eyes are in comparison with the "morning sun of heaven / Better becomes the grey cheeks of the east" (1l. 5-6) and "full star that ushers in the even / Doth half that glory to the sober west" (11. 7-8), the result is that the two black eyes are more pretty than the morning sun as well as the full star, as they "become thy face", in other words, "mourning" eyes make her even more attractive to the speaker. The climax is reached in the concluding couplet:

Then I will swear beauty herself is black,

And all they foul that thy complexion lack. (11. 13-14) 
The speaker promises to swear that beauty itself is black, here he amplifies the lady's beauty by rendering any other conventional images of fairness "foul." The mourning blackness of the mistress's dark beauty becomes her so suited that it persuades all who see her that this is what true beauty should be. So to speak, the beauty of blackness is improved to the highest level.

From the above analysis, we know that it is definitely true that the physical outstanding fair beauty of the young man and the dark lady's unconventional black beauty are interpreted abundantly in the Sonnets. Beauty in the Sonnets is not only a source of ethical benefit but also of esthetic delight which is a necessary quality that qualifying verse should have in the Renaissance time. It is well-known that the proposition of one of the ends of poetry should be pleasing by Horace and later it is developed by Sir Philip Sidney. The delights of poetry are recommended by many Renaissance poets. Sir Philip Sidney's observations of the delights of poetry are much significant. As Thompson comments that Sidney's "conception of aesthetic values in poetry attaches great importance to the power of the art in the lives of men through its appeal to the emotions." (Thompson, 1914, p. 125) Delight, as one of aesthetic values in poetry, is represented in various forms in different verses. Shakespeare's Sonnets, by virtue of beauty in physical dimension, enact the readers to be delightful, which evidently embodies the poet's poetic aesthetics.

\section{The Sensual Pleasure from Desires}

One of the obvious features of the Sonnets is its frankness about sex, which distinguishes it from others of the period (Note 4). There are several aspects concerning sex, including homosexuality, heterosexuality, love triangle, and auto-sexuality, these studies do attempt to "reveal the cultural life in the literary, sexual, social, economic, and historical discourses that shaped Shakespeare and that Shakespeare shaped into poems" (Schiffer, 1999, p. 45).

In a sharp departure from the gender conventions of Petrarchan poetry more generally, the Sonnets trigger a very different kind of sexual experience. As Pequigney argues that Shakespeare's sonnets are suffused with evidence of erotic desire between men has been the focus - explicitly or implicitly — of commentary on the sonnets since the seventeenth century (Pequigney, 1985). It is true that several of the poems unmistakably refer to sexual organs and activity, and in some other sonnets sex is apparent by being lightly veiled under a thin cover of wordplay. Paul Hammond notes that the "language of the Sonnets has sexual connotations" which are more semantically unstable (Hammond, 2002, p. 70), as the language is used, in a poetic way, explicitly or suggestively. The expression of desire runs through the whole sequence. In the first 126 sonnets, Stephen Booth points out that in which are "full of incidental and incidentally bawdy sexual innuendo; some references make literal sense in reference to either male or female organs; some are specially male, some specifically female [e.g., the con-, cun- jokes]" (Booth, 1977, p. 548). The procreation theme in the first seventeen sonnets cannot separate from sex. Procreation is a means of overcoming the effects of time and on the way in which the beauty is preserved. Sonnet 1 introduces the poet's endeavour to persuade the young man to make a copy of his beauty, as Paul Edmondson states that, this poem has a veiled allusion to masturbation as the speaker deplores the young man feeding his "light's flame with self-substantial fuel" (1. 6), probably, it implies that he pleasures himself by producing his own semen which is "buried," yet not using it for procreation (Edmondson \& Wells, 2004, p. 72). The young man is blamed for "having traffic with thyself alone" (1. 9), in Sonnet 4, which also has a masturbating implication like the first poem (Note 5), expending sexual energy upon himself. The other sexual words as "husbandry," "unearned," "womb," and "use," in Sonnets 2, 3, 4, 6, and 9, through the wordplay, indicate that begetting children like the farming, ploughing the womb, and sowing it with seed (semen) leads to children, as ploughing and sowing the land leads to crops. According to the physiology of the time, the male seed was the substance which created a child, and the woman was simply a carrier of the developing embryo. Partridge summarizes that "we have the seeding-cultivation-harvesting metaphor so common in Shakespeare when he wishes to speak of semen-sowing and sexual tillage" (Partridge, 1968, p. 125). There is overt sexual referent in Sonnet 6, lines 3 and 4-Make sweet some vial; treasure thou some place / With beauty's treasure ere it be self-skilled-identify delicately of a potential bride's vagina as "some vial" and "some place" which the young man may "make sweet" with his semen as "beauty's treasure" before "it be self-skilled."

The most frequently discussed sonnet in relation to sexuality, in Fair Young Man group, is Sonnet 20. In it the speaker nakedly complains that Nature's joke "by adding one thing" upon the young man is "to my purpose nothing," a "thing" is slang for penis, and "nothing" female's genitals (Hammond, 2002, p. 16). The couplet reinforces the idea whereby bawdy pun, "But since she pricked thee out for women's pleasure, / Mine be thy love, and thy love's use their treasure", the sense of "prick out" is "select," according to Partridge, "prick" refers to penis, so that this phrase "pricked thee out" can be understood as "furnished you with a penis," designed "for women's pleasure"- to give sexual pleasure to women. Booth illustrates that the specifically sexual sense of 
"pleasure" survived into modern times in the expression "to have one's pleasure" of a woman. See Genesis 18. 12, the Geneva text presents "Therefore Sarah laughed within her selfe, saying, After I am waxed olde, \& my lord also, shall I have lust?" (Booth, 1977, p. 165) Therefore, this sonnet is crucial to judge whether there is a possibility of homosexual relationship between the speaker and the young man, ever since the sex studies of the Sonnets. We consent to A. L. Rowse's, Paul Hammond's, Stephen Orgel's, Culin Burrow's (Note 6), and other commentators' interpretation that the apparent denial of sexual interest in the young man is undone by the word "nothing" is slang for the female genitals, so the women's pleasure the young man is "pricked out for" is not the pleasure he gives women but he has the ability to do. It is noticeable that Sonnet 20 is the only poem in the sequence using feminine rhyme (Note 7), which is clustered at moments of transgressive passion. Probably, it is another game the poet plays, besides the wordplay, to foreground the seductive sexuality.

The threatening sexuality that the dark lady represents is more explicit than almost anything suggested in the poems to the young man. The Will Sonnets 135,136 and Sonnet 151 are overtly physical in its expression of desire. The two noted Will Sonnets 135 and 136 ring the changes on the potential bawdy connotations of one word, "will". Any reader of the Sonnet 135 and Sonnet 136 soon realizes that the hidden meanings are of greater importance than the surface meaning.The word "will" appears 20 times in all in the two poems, readers in any case have to bear in mind the large numbers of meanings which the word carries, and allow in each case the relevant suggestions to filter into their minds. According to Partridge, “'will' means a passionate, or a powerful, sexual desire.There are several similar occasions in Shakespeare's plays, for instance, Lucrece, v. 243, where Tarquin, preparing to rape Lucrece, says, 'my will is strong, past reason's weak reproving'; and v. 247, 'Tween frozen conscience and hot burning will" (Partridge, 1968, p. 218). Will, in the sense of "volition" or "resolution," it can imply something as certain of being put into effect as a last will and testament. But it can also imply inconstant willfulness; and in the sense of "desire" it is the passion which Elizabethan psychology held to be least amendable to the Will (Mahood, 1968, p. 52). In the two sonnets, the word "will" is repeated in a variety of contexts paired with rhyming words, an act that successfully displays both the quantity and quality of wit and humor one can showcase in each sonnet. Stephen Booth calls them are festivals of verbal ingenuity in which much of the fun derives from the grotesque lengths the speaker goes to for a maximum number and concentration of puns on "will" (Booth, 1977, p. 466). Commentators have identified six or seven relevant meanings (not all of them bawdy): 1) wishes, (2) carnal desire, (3) the male sexual organ, (4) the female sexual organ, (4) a lover-Shakespeare?-named Will, (5) name of the speaker's friend, (6) name of the dark lady's husband.

The first quatrain of Sonnet 135, in it the speaker declares that Will's lover (the dark lady) needs no one but him, for she already has more of him than she can deal with:

Whoever hath her wish, thou hast thy Will,

And Will to boot, and Will in overplus;

More than enough am I that vex thee still,

To thy sweet will making addition thus.

As the speaker wants to continue the sexual relationship with his mistress, though she is already bursting with lovers, he pleads he can be allowed to have sex with the mistress, that is, to put his "will" into the dark lady's "sweet will," sweet amorous desires, sweet cunt. And then, in second quatrain, the speaker uses euphemisms to count the mistress's generous sexual behavior with others, since she has such large and insatiable sexual desires and who is so willing to accommodate all lovers, here her "will," which refers to sex organ, is large and spacious. Employing the image of the sea as a simile of the woman, in the third quatrain, the speaker argues that the sea can continue to receive water from all sources, despite its wealth thereof, so the mistress should follow such an eloquent example and take all those who desire her and add her store of will. All wills are alike for the lover, taking one is like taking another. In the last line, the speaker utters that his will is not different from other many wills the mistress has already admitted. Sonnet 136 continues to play on the sexual innuendoes of "will" and expands it further into various puns on "something" and "nothing," as "something" and "nothing" were the Elizabethan slang terms for sexual organs, both male and female. As in Sonnet 135, it is not easy to say clearly how many connotations of the word "will" are involved, it seems that whichever explanation to be justifiable, however, preserving the meanings' multiplicity is better. The predominant meaning of the content of this sonnet seems to be the physical one of sexual intimacy, both in the sense of the speaker pushing himself upon the lover, and also in the sense of having an orgasm. Molly Mahood points out in Shakespeare's Wordplay, when Elizabethan rhetoricians spoke of the power and force of words, their meaning may have been as much literal as metaphorical (Mahood, 1968, p. 171). For all of the poet's play on phrases like "I come so near," "things of great 
receipt,"“store's account," "nothing"and "a something, sweet," of which the bawdy senses are apparent (Note 8). It is worthy to note that the words "sweet" (lines 4, 12) and "pleasing" (line 11) run through the poem accompanying with so many "wills." Both "sweet" indicates, besides the might be epithet in direct address, pleasure which is brought by sexual activity. Lines 11 and 12-For nothing hold me, so it please thee hold / That nothing me, something sweet to thee-demonstrate distinctly that the erotic pleasures they would have, the speaker tells his mistress that just considering him to be a mere sexual object which is pleasurable and sweet to her, so long as she also takes pleasure in thinking him to be a sweet thing in the mistress's company.

There is no exaggeration to say that the most crudely physical desire is expressed in Sonnet 151, which is also aroused many critics' discontent with the poet. It is overt that this sonnet is full of words signifying sexual desire, for instance, "flesh," "rising," "point," "proud," "stand," "fall," "rise and fall," and "conscience" (Note 9), so the language of this poem the poet employs is as far as possible to get from the conventions of sonnet literature. Bawdily, the speaker degrades the relationship with his mistress to an erotic level in which the image of his erect penis is the controlling image of the sonnet. The "flesh" rises at the dark lady's name and points at her, which is the obvious reference to sexual erection, the speaker is proud of this "pride" (1.10) and delight that it should be the mistress's slave in sexual performance. The couplet-No want of conscience hold it that I call / Her 'love', for whose dear love I rise and fall- "might almost be spoken by the penis itself" (Edmondson \& Wells, 2004, p. 77). It is doubtless true that most frankness about sexuality is one of the striking characteristics of the Dark Lady sonnets.

Just like the first line of the first sonnet tells us that- "from fairest creatures we desire increase"-the unsurpassed beauty is desired to create more, which opens the whole sonnet sequence with a sexual tone to present infinite possibilities of physical desire. The poet's most frankness towards sexuality must have surprised the readers, even modern ones. Danielle Clarke states that the ultimate fleeting expression in sexual desire, for Shakespeare, is at the heart of human life (Clarke, 2007, p. 181). In a broad sense, the expression of sexuality embodies the way to know about human in Renaissance time. The two popular genres of literature in Renaissance - poetry and drama - pay more attention to human sexuality in order to reclaim and amuse the readers and audiences. The sexual language and amorous puns are filled with Shakespeare's plays still can make today's readers feel flushed. His narrative poems, both Venus and Adonis and The Rape of Lucrece, dealing with the erotic themes, and in terms of delight, "afford pleasures in their different ways" (Roe, 2007, pp. 33-34).

\section{Conclusion}

Indeed, sexuality can engender pleasure, but if it violates married chastity, social norms, it would bring death and destruction, as in The Rape of Lucrece the "price of sexual consummation is death" (Clarke, 2007, p. 184), for both Tarquin and Lucrece. As the speaker, in Sonnet 147, admits that his desire for the black mistress is a fever, because of his straying from reason and truth too far (11. 9-12), so that "Desire is death" (1. 8), which is also the poet's admonition for mankind. This kind of erotic playfulness is a feature of the Sonnets, as well as Shakespeare's work in general, the admirable quality that it opens up the interpretation of them in such a broad and extravagant variety of possibilities.

What Shakespeare had done with the beauty shows his aesthetics which reflected the century theme of "carpe diem." "Carpe diem," a Latin term, means to seize the day, to enjoy and to make use of, to make merry while you can.The joy, pleasure and delight getting from the life are certainly highlighted, and merry making between man and woman is the main focus of them. This is one of the principal features of humanism, in Renaissance Movement, that foregrounds the role and life of human kind. The interpretation of pleasure of desire in Shakespeare's Sonnets demonstrates its influences of "carpe diem." The account of sexual pleasure shows that on the one hand for enjoying the life itself, on the other hand, for leaving children behind to make the temporary time eternalized, thus returning back to timeless Garden of Eden. This returning course is the process of preserving beauty.

\section{Acknowledgement}

This paper is part of the Research Program of the National Social Sciences Fund: 13CWW025.

\section{References}

Baldwin, T. W. (1950). On the Literary Genetics of Shakespeare's Poems \& Sonnets. Urbana: University of Illinois Press.

Booth, S. (1977). Shakespeare's Sonnets, edited with analytic commentary by Stephen Booth. New Haven and London: Yale University Press.
Callaghan,
D. (2007).
Shakespeare's
Sonnets.
Oxford:
Blackwell
Publishing. 
http://dx.doi.org/10.1002/9780470774878

Clarke, D. (2007). Love, beauty, and sexuality. In P. Cheney (Ed.), The Cambridge Companion to Shakespeare's Poetry (pp. 181-201). Cambridge: Cambridge University Press. http://dx.doi.org/10.1017/CCOL0521846277.011

Edmondson, P., \& Wells, S. (2004). Shakespeare's Sonnets. New York: Oxford University Press.

Hammond, P. (2002). Figuring Sex between Men from Shakespeare to Rochester. Oxford and New York: Oxford University Press. http://dx.doi.org/10.1093/acprof:oso/9780198186922.001.0001

Harrison, J. S. (1903). Platonism in English Poetry of the Sixteenth and Seventeenth Centuries. New York: Macmillan Publishing Company.

Hubler, E. (1952). The Sense of Shakespeare's Sonnets. Princeton: Princeton University Press.

Mahood, M. (1968). Shakespeare's Wordplay. London and New York: Methuen.

Matz, R. (2008). The World of Shakespeare's Sonnets: An Introduction. London: McFarland \& Company.

Medcalf, S. (1994). Shakespeare on beauty, truth and transcendence. In A. Baldwin \& S. Hutton (Eds.), Platonism and the English Imagination. Cambridge: Cambridge University Press. http://dx.doi.org/10.1017/CBO9780511553806.012

Muir, K. (1979). Shakespeare's Sonnets. London: George Allen \& Unwin.

Partridge, E. (1968). Shakespeare's Bawdy. London and New York: Routledge.

Pequigney, J. (1985). Such Is My Love: A Study of Shakespeare's Sonnets. Chicago: University of Chicago Press.

Plato. (1854). Hippias Major. In B. George (Ed.), The works of Plato: a new and literal version. London: Henry G. Bohn.

Roe, J. (2007). Rhetoric, style, and poetic form. In C. Patrick (Ed.), The Cambridge Companion to Shakespeare's Poetry (pp. 33-53). Cambridge: Cambridge University Press. http://dx.doi.org/10.1017/CCOL0521846277.003

Schiffer, J. (1999). Shakespeare's Sonnets: Critical Essays. London and New York: Garland Publishing Company.

Thompson, G. A. (1914). Elizabethan Criticism of Poetry. Menasha.

Vendler, H. (1998). The Arts of Shakespeare's Sonnets. Cambridge and London: the Belknap Press.

Vyvyan, J. (1961). Shakespeare and Platonic Beauty. London: Chatto \& Windus Ltd.

West, D. (2007). Shakespeare's Sonnets: with A New Commentary. London, New York, Woodstock: Duckworth Overlook.

\section{Notes}

Note 1 . The word beauty is mentioned sixty nine times throughout the Sonnets, they are in Sonnets 1, 2, 4, 5, 6, 7, $9,10,11,12,13,14,17,19,21,22,24,27,34,37,41,53,54,60,62,63,65,67,68,69,70,77,79,83,84,93$, $95,101,104,106,115,127,131,134,137$, and 150 .

Note 2. The theme of sleepness and separation is a traditional one, echoing Sidney and other sonneteers, who recount how they were stricken by being separated from their beloved. Here is the example of Sonnet 89 from Astrophel and Stella: Now that of absence the most irksome night With darkest shade doth ouercome my day; / Since Stella's eyes, wont to giue me my day, / Leauing my hemisphere, leaue me in night, / Each day seemes long, and longs for long-staid night; / The night, as tedious, woos th' approch of day: / Tired with the dusty toiles of busie day, / Languisht with horrors of the silent night; / Suffering the euils both of day and night, / While no night is more darke than is my day, / Nor no day hath lesse quiet then my night: / With such bad mixture of my night and day, / That liuing thus in blackest Winter night, / I feele the flames of hottest Summer day. In it the speaker cries that how he suffers from the absence of his lover both during day and night, while, how Stella looks like is not mentioned. See Sir Philip Sidney, 1873, The Complete Poems of Sir Philip Sidney, edited with essay on the life and writings, and notes and illustration by Rev. Alexander B. Grosart, vol. 1 (London: Robson and Sons), pp. 58-59.

Note 3. Like Leishman's complaint, this theme had been already touched upon by most Elizabethan sonneteers. This sonnet, most commentators consider that, was strongly influenced by the sonnet written by Henry Constable. For the sake of making clear the similarities and differences between the two sonnets, and we can recognize 
Shakespeare's indebtedness to conventions and his transcendence on a traditional theme, here, I quote Constable's in full: My Lady's presence makes the Roses red, / Because to see her lips they blush for shame; / The Lilies' leaves (for envy) pale became, / And her white hands in them this envie bred. / The Marigold the leaves abroad doth spred, / Because the sunne's and her power is the same; / The Violet of purple cullour came, / Di'd in the blood shee made my hart to shed. / In briefe, all flowers from her their vertue take; / From her sweet breath their sweet smels doth proceede; / The living heate which her eye beames doth make / Warmeth the grounde, and quickeneth the seede. / The raine wherewith she watereth the flowers / Falls from mine eyes, which she dissolves in showers. See Henry Constable, 1897, The Poems \& Sonnets of Henry Constable (Berkeley: University of California), p. xxx.

Note 4. Sexuality of the Sonnets is a hot topic attracts many commentators to delve into, especially the homosexuality. The homoerotic interpretation had been offered as early as the late nineteenth century by Oscar Wilde and Samuel Butler in their The Portrait of Mr. W. H. and Shakespeare's Sonnets Reconsidered respectively. See Oscar Wilde, 1958, The Portrait of Mr. W. H. (London: Methuen \& Co Ltd.), Samuel Butler, 1927, Shakespeare's Sonnets Reconsidered (London: Jonathan Cape). The general acceptance of gay and bisexual readings of the Sonnets is emerged and developed in the last decade of 20th century, thanks mainly to studies by Eve Kosofsky Sedgwick, Joseph Pequigney, Bruce R. Smith, Jonathan Goldberg, Gregory Bredbeck, Marjorie Garber, and others. This commentary also appears in the introductions to recent editions of the Sonnets, Helen Vendler recognizes and Duncan-Jones strongly emphasizes the homoeroticism of the first subsequence. And many other scholars take strenuously efforts in their essays to reveal the great explanatory power of gender studies, such as, Peter Stallybrass's "Editing as Cultural Formation: The Sexing of Shakespeare's Sonnets," Bruce R. Smith's "I, You, He, She, and We: On the Sexual Politics of Shakespeare's Sonnets," Valerie Traub's "Sex without Issue: Sodomy, Reproduction, and Signification in Shakespeare's Sonnets," and so on.

Note 5. As Booth says that "having traffic with thyself alone" not only means keeping yourself single, but specially suggests masturbating connotation. See Stephen Booth, ed., 1977, Shakespeare's Sonnets, edited with analytic commentary, p. 140.

Note 6. See A. L. Rowse, ed., Shakespeare's Sonnets: with an Introduction and Notes, p. 43; Paul Hammond, p. 16; Stephen Orgel, Impersonations: The Performance of Gender in Shakespeare's England (Cambridge: Cambridge University Press, 1996), p. 57; Culin Burrow, 2002,Introduction to William Shakespeare: The Complete Sonnets and Poems (Oxford: Oxford University Press), pp. 128-130.

Note 7. Feminine rhyme is the technical term for a hypermetrical line with an additional unstressed final syllable, it is relatively rare in English poetry and usually appears as a special effect. According to Culin Burrow, Samuel Daniel (c. 1603) was the first who used the rhymes, which often occur at sexually suggestive moments, as in Hero and Leander 11. 555-558.

Note 8. The sexual meaning of "to come" was well established in Shakespeare's time, according to Partridge, although it was probably not as prevalent as in our own. See Eric Partridge, Shakespeare's Bawdy, p. 89; Stephen Booth states that "account" is a synonym for the bawdy senses of "a treasure," "a nothing," and one sense of “will." See Stephen Booth, ed., 1977, Shakespeare’s Sonnets, edited with analytic commentary, pp. 471-472.

Note 9. The word "conscience," which means ability to recognize right and wrong, derives from Latin con ("together") and scire ("to know"), Stephen Booth interprets that here Shakespeare seems to derive a reading of conscience that is roughly paraphrasable as "cunt knowledge." So the word "conscience" carries the sense of the female sex organ. See Stephen Booth, ed., 1977, Shakespeare’s Sonnets, edited with analytic commentary, p. 526 .

\section{Copyrights}

Copyright for this article is retained by the author(s), with first publication rights granted to the journal.

This is an open-access article distributed under the terms and conditions of the Creative Commons Attribution license (http://creativecommons.org/licenses/by/3.0/). 